\title{
Using ICP-OES and SEM-EDX in biosorption studies
}

\author{
Izabela Michalak • Katarzyna Chojnacka • \\ Krzysztof Marycz
}

Received: 8 June 2010 / Accepted: 13 September 2010 / Published online: 25 September 2010

(C) The Author(s) 2010. This article is published with open access at Springerlink.com

\begin{abstract}
We have compared the analytical results obtained by inductively coupled plasma optical emission spectroscopy (ICP-OES) and by scanning electron microscopy with an energy dispersive X-ray analytical system (SEM-EDX) in order to explore the mechanism of metal ions biosorption by biomass using two independent methods. The marine macroalga Enteromorpha sp. was enriched with $\mathrm{Cu}(\mathrm{II}), \mathrm{Mn}$ (II), $\mathrm{Zn}(\mathrm{II})$, and $\mathrm{Co}(\mathrm{II})$ ions via biosorption, and the biosorption capacity of alga determined from the solution and biomass composition before and after biosorption process was compared. The first technique was used to analyze the composition of the natural and metal-loaded biomass, and additionally the composition of the solution before and after biosorption. The second technique was used to obtain a picture of the surface of natural and metal ion-loaded macroalgae, to map the elements on the cell wall of dry biomass, and to determine their concentration before and after biosorption. ICP-OES showed a better precision and lower detection limit than EDX, but SEM-EDX gave more information regarding the sample composition of
\end{abstract}

Electronic supplementary material The online version of this article (doi:10.1007/s00604-010-0468-0) contains supplementary material, which is available to authorized users.

I. Michalak $(\bowtie) \cdot$ K. Chojnacka

Institute of Inorganic Technology and Mineral Fertilizers,

Wrocław University of Technology,

Smoluchowskiego 25,

PL-50-372 Wrocław, Poland

e-mail: izabela.michalak@pwr.wroc.pl

K. Marycz

Department of Hygiene and Ichtiology,

Electron Microscope Laboratory,

Environmental and Life Science University,

Chełmońskiego 38c,

PL-50-630 Wrocław, Poland
Enteromorpha sp. Both techniques confirmed that biosorption is a surface phenomenon, in which alkali and alkaline earth metal ions were exchanged by metal ions from aqueous solution.

Keywords Biosorption · Microelement ions · Macroalga Enteromorpha sp. $\cdot$ ICP-OES $\cdot$ SEM-EDX

\section{Introduction}

Biosorption is a surface phenomenon. This term describes the passive binding of metal ions from aqueous solutions by non-living biomass, which implies that the process is not metabolically controlled [1]. In the literature, biosorption is analyzed with the use of techniques, which determine not the concentration of metal ions bound on the biomass surface, but either the total concentration in the biomass (by analysis of elemental composition of the biomass digested with concentrated mineral acids) or most frequently-from the mass balance, by subtraction of the equilibrium concentration of metal ions in the solution $\left(C_{\text {eq }}\right)$ from their initial concentration $\left(C_{0}\right)$ and dividing per the concentration of the biosorbent $\left(C_{\mathrm{X}}\right)$, using the following formula: $q^{\mathrm{S}}=$ $\left(C_{0}-C_{\mathrm{eq}}\right) / C_{\mathrm{X}}[2-5]$.

Denkhaus et al. (2007) in the review entitled 'Chemical and physical methods for characterisation of biofilms' presented techniques, which are commonly used for characterization of surfaces and interfaces, e.g. microscopic, spectroscopic and microsensoric [6]. Among them, to the most popular methods, which are used to analyze metal ions both in the biomass and in the solution are as follows: AAS (Atomic Absorption Spectroscopy) [7-9], ICP-OES (Inductively Coupled Plasma with Optical Emission Spectroscopy) [10-12], ICP-MS (Inductively Coupled Plasma 
Mass Spectrometry) [13]. Although all the techniques are precise and sensitive, it is impossible to distinguish between metal ions bound by the biomass surface and those accumulated inside the cell. The application of analytical techniques such as: TEM (Transmission Electron Microscopy) [12, 14], Energy-Dispersive X-ray Spectroscopy (EDX) $[12,14]$ or SEM (Scanning Electron Microscopy) [14-16] enables to determine the elemental composition of the cell wall and to trace the distribution of metal ions on the surface of the cell. This technique was also used to examine the samples of macroalgae: Sargassum sp. [16], Sargassum vulgaris [17], Durvillaea potatorum [18].

In the present paper, two techniques were applied: ICPOES and SEM-EDX in order to understand the mechanism of biosorption of microelement ions (Cu(II), $\mathrm{Zn}$ (II), Co(II) and $\mathrm{Mn}(\mathrm{II})$ ) by marine macroalga Enteromorpha sp. The advantages and disadvantages of each technique are discussed in Fig. 1. Generally, an ICP-OES analysis can detect an average concentration, the SEM-EDX system can analyze an area of the sample as big as the size of the electron beam. In SEM-EDX method, sample preparation is fast and easy compared to the dissolution process necessary for conventional atomic spectroscopy. However, ICP-OES has the advantage of lower detection limits with a higher accuracy, even for the light elements, compared to the SEM-EDX [19].

In the literature it is reported, that biosorption of metal ions by the biomass could occur according to ion-exchange mechanism, whereby acidic functional groups in the biomass exchange protons and/or cations of alkaline earth metals $(\mathrm{Mg}, \mathrm{Ca}, \mathrm{Be}, \mathrm{Ba})$ and alkali metals $(\mathrm{Na}, \mathrm{K}, \mathrm{Li})$ with metal ions from aqueous solutions $[1,11]$. The postulated cation exchange mechanism is probably due to the presence of anionic functional groups on the surface of the cells. The cell wall of Enteromorpha contains a high level of polysaccharides - up to $63 \%$ of cell wall dry weight, $13.8 \%$ of lipids (total), $9.2 \%$ of protein and a small quantity $(0.3 \%)$ of glucoseamine. These macromolecules offer host of functional groups such as: carboxyl, hydroxyl, imidazole, amino, N-acetyl, phosphate etc. [20].

The aim of the present work was to prove that elements, which are naturally bound by macroalga (Enteromorpha sp.) are exchanged with metal ions from aqueous solution in the biosorption process. For this purpose, ICP-OES method together with SEM-EDX technique were used to evaluate the concentration of elements before and after biosorption in the dry biomass of Enteromorpha sp., to determine the elemental content in the solution before and after process by ICP-OES method and additionally to map elements on the surface of macroalgal cell wall by using Scanning Electron Microscope. These two techniques were also useful in identification of the mechanism of biosorption. In this paper, biosorption capacity of macroalga Enteromorpha sp. was determined not only from the mass balance, but also from the analysis of the digested biomass by ICP-OES and also from SEM with mapping. Additionally, the aim of this paper was also to indicate, which value is the most appropriate. Biosorption experiments were
Fig. 1 The advantages and disadvantages of ICP-OES and SEM-EDX techniques

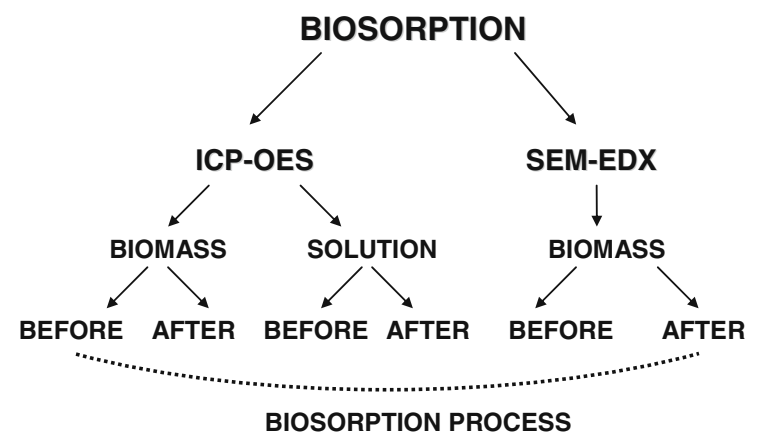

\section{ICP-OES (BIOMASS)}

的

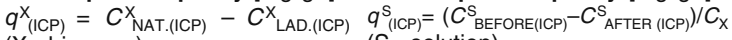
(X - biomass)

-Visible difference in the biomass -Indirect method, but direct composition before and after analysis biosorption process

-Direct method preceded by biomass mineralization (indirect analysis)

-Dillution of sample about 100 times

-Interferences from other components of the biomass (e.g. $\mathrm{Fe})$

\section{SEM-EDX (BIOMASS)}

- Biosorption capacity [\%]: $q^{\mathrm{SEM}}=\%$ surface coverage $\mathrm{BEFORE}-\%$ surface coverage $_{\text {AFTER }}$

-semiquantitative method of determination of the surface composition (low sensitivity)

-Analysis of the surface composition of the biomass, identification of visible elements only.

-Biosorption capacity expressed in \% of surface coverage not in $\mathrm{mg} / \mathrm{g}$.

-The possibility of comparison, which elements appeared or disappeared after biosorption process (important for mechanism identification)

-The possibility of observation of morphological changes, e.g. shrinking 
carried out on microelement cations: $\mathrm{Cu}(\mathrm{II}), \mathrm{Zn}(\mathrm{II}), \mathrm{Co}(\mathrm{II})$ and $\mathrm{Mn}(\mathrm{II})$. In order to fully understand this process, it was necessary to carry out mentioned investigations.

\section{Experimental}

\section{Organism}

The macroalga Enteromorpha sp. was collected from the Baltic Sea (Gdańsk - Brzeźno - Poland) in April 2007. The biomass was washed with tap water several times to remove foreign matter and afterwards with deionized water three times. Then, the biomass was dried at $60{ }^{\circ} \mathrm{C}$ until the constant mass was reached.

\section{Biosorption experiments}

The biosorption experiments were performed in Erlenmeyer flasks, containing $500 \mathrm{~mL}$ of microelement ions (Mn(II), $\mathrm{Cu}(\mathrm{II}), \mathrm{Co}(\mathrm{II})$ and $\mathrm{Zn}(\mathrm{II}))$ in thermostated water bath shaker at $150 \mathrm{rpm}$. Initial concentration of each metal ion was $150 \mathrm{mg} \mathrm{L}$. The maximum biosorption capacity of the examined metal ions was determined in our previous work [21]. The biomass concentration in the experiments was $1.0 \mathrm{~g} \mathrm{~L}^{-1}$. The solutions of metal ions were prepared in deionized water (by dissolving appropriate amounts of $\mathrm{MnSO}_{4} \cdot \mathrm{H}_{2} \mathrm{O}, \mathrm{CuSO}_{4} \cdot 5 \mathrm{H}_{2} \mathrm{O}, \mathrm{CoSO}_{4} \cdot 7 \mathrm{H}_{2} \mathrm{O}, \mathrm{ZnSO}_{4} \cdot 7 \mathrm{H}_{2} \mathrm{O}$ (from POCh S.A. Gliwice, Poland, www.english.poch. com.pl/)). The contact time was evaluated from previous kinetic experiments as $4 \mathrm{~h}$ for Enteromorpha sp. [22]. $\mathrm{pH}$ of the solutions was adjusted to 5 with $0.1 \mathrm{~mol} \mathrm{~L}^{-1}$ standardized solution $\mathrm{NaOH} / \mathrm{HCl}$ (from POCh S.A. Gliwice, Poland). $\mathrm{pH}$ measurements were conducted with $\mathrm{pH}$-meter Mettler-Toledo-Seven Multi (Greifensee, Switzerland, www.mt.com) equipped with an electrode InLab413 with compensation of temperature. After biosorption process, the suspension of macroalga was filtered through the filter paper and the separated enriched biomass was dried and underwent ICP-OES multielemental analysis and next SEM (EDX).

Analytical methods

\section{Multielemental analysis by ICP-OES}

The samples of natural and the biomass of Enteromorpha sp. loaded with microelements (c.a. $0.5 \mathrm{~g}$ ) were digested with $6 \mathrm{~mL}$ of concentrated-69\% $\mathrm{HNO}_{3}$ supra-pure grade from Merck (Darmstadt, Germany) in Teflon vessels with the use of microwave oven Milestone MLS-1200 (Bergamo, Italy). After mineralization, the samples were diluted to $50 \mathrm{~g}$. The mineral content of macroalga as well as the concentration of elements in the solutions before and after biosorption process were analyzed by Inductively Coupled Plasma-Optical Emission Spectrometer-Varian VISTAMPX ICP-OES (Victoria, Australia) with ultrasonic nebulizer in the Chemical Laboratory of Multielemental Analyses at Wrocław University of Technology, which is accredited by ILAC-MRA and Polish Centre for Accreditation (No. AB 696) according to EN-ISO 17025 [23].

\section{Validation of the method}

For the calibration of the apparatus, the multielemental standard (100 mg L ${ }^{-1}$ Astasol ${ }^{\circledR}$, Czech Republic, www. analytika.net) was used. In order to prepare the calibration curve, the following working dilutions of the analytical standard were prepared: $1.0,10,50 \mathrm{mg} \mathrm{L}^{-1}$. As a "check standard", the standard solution-10 $\mathrm{mg} \mathrm{L}^{-1}$ was used after each series of 20 samples. The acceptable result was assessed as $10 \%$.

The analytical process was controlled by the use of Certified Reference Material Hard Drinking Water (UK) metals from LGC Standards (www.lgcstandards.com) (LGC6010) for analysis of solutions and Polish Certified Reference Material for multielement trace analysis Oriental Tobacco Leaves (CTAOTL-1) from Institute of Nuclear Chemistry and Technology (Poland, www.ichtj.waw.pl) for the analysis of digested samples of the biomass. Values of the measurements of the CRMs were within the certified range.

The examined samples were measured in three repeats. The final result was an arithmetic mean, which differed less than $5 \%$.

\section{Scanning electron microscopy}

Natural and loaded with microelements biomass of Enteromorpha sp. was also examined by Scanning Electron Microscopy (SEM). The elemental analysis and mapping was performed at Wroclaw University of Environmental and Life Sciences (Electron Microscope Laboratory). Samples of macroalaga were fixed in $2.5 \%$ of glutaraldehyde (Sigma, www.sigmaaldrich.com). Then all the samples were dehydrated by ethanol (from 30\% till 100\% concentration). In the next step macrolaga was prepared in two planes for the observation of cross-section and its surface. Samples of the macroalga were mounted on appropriate stub, and thereafter gold-sputtered (using ScanCoat six equipment-Oxford) and were observed and photographed with a Scanning Electron Microscope-Leo Zeiss 435 VP SEM (Oberkochen, Germany), operating at $20 \mathrm{kV}$. The microscope was equipped with a RONTEC energy dispersive X-ray system in order to obtain information on elemental composition of the surface of macroalgal 
cell wall. The X-ray spectrum of each macroalga loaded with a given microelement was obtained.

\section{Results and discussion}

\section{Multielemental analysis by ICP-OES}

ICP-OES method was used to determine the mineral composition of the natural and loaded with microelements macroalgal biomass in a single-metal system (MA-Mn, MA$\mathrm{Zn}, \mathrm{MA}-\mathrm{Cu}, \mathrm{MA}-\mathrm{Co}$, where MA means macroalga) and the concentration of elements in the solution before and after biosorption process. This technique was used to identify the mechanism of biosorption process and also to indicate differences in the calculation of biosorption capacity of the biosorbent towards metal ions from the mass balance and from the natural and loaded biomass composition.

\section{Analysis of the solution before and after biosorption process}

On the basis of the composition of the solution it was observed that in the case of the biomass: MA-Cu and MA-Zn, light metal ions were released in the following order: $\mathrm{Na}(\mathrm{I})>\mathrm{Ca}$ (II) $>\mathrm{Mg}(\mathrm{II})>\mathrm{K}$ (I). During biosorption of $\mathrm{Mn}$ (II) and $\mathrm{Co}(\mathrm{II})$ ions, $\mathrm{Ca}(\mathrm{II})$ ions were bound by the biomass, and the remaining light metal ions were released as follows: $\mathrm{Na}(\mathrm{I})>\mathrm{Mg}(\mathrm{II})>\mathrm{K}(\mathrm{I})$. The order of the release of light metals could be connected with the mineral composition of the natural biomass of Enteromorpha sp., in which the content of light metals was as follows: $\mathrm{Na}$ (I) $>\mathrm{Ca}$ (II) $>\mathrm{Mg}$ (II) $>\mathrm{K}$ (I) $\left(16,283 \mathrm{mg} \mathrm{kg}^{-1}\right.$ d.m. $>$ $9,550 \mathrm{mg} \mathrm{kg}^{-1}>8,814 \mathrm{mg} \mathrm{kg}^{-1}>3,920 \mathrm{mg} \mathrm{kg}^{-1}$, respectively). It is also important to mention that high concentration of $\mathrm{Na}(\mathrm{I})$ ions in the initial solution could result from $\mathrm{NaOH}$, which was used to adjust the initial $\mathrm{pH}$. The relationship between amount of light metal cations released from the biomass ( $q$ (released) $-q(\mathrm{r}) ; \mathrm{mg} \mathrm{g}^{-1}$ or meq $\mathrm{g}^{-1}$ ) and their content in the natural biomass determined by ICP-OES $\left(C^{\mathrm{X}}{ }_{\text {NAT.(ICP); }} \mathrm{mg} \mathrm{kg}^{-1}\right)$ is presented as the following equations: for MA-Mn: $q(\mathrm{r})=0.00110 \cdot C^{\mathrm{X}}{ }_{\mathrm{NAT} .(\mathrm{ICP})}-1.50(R 0.998)$; for MA-Zn: $q(\mathrm{r})=0.00160 \cdot C^{\mathrm{X}}{ }_{\mathrm{NAT} .(\mathrm{ICP})}-4.36(R 0.995)$; for MA-Co: $q(\mathrm{r})=0.00120 \cdot C^{\mathrm{X}}{ }_{\mathrm{NAT} .(\mathrm{ICP})}-1.77(R 0.988)$ and for $\mathrm{MA}-\mathrm{Cu}: q(\mathrm{r})=0.00110 \cdot C^{\mathrm{X}}{ }_{\text {NAT.(ICP) }}-1.09$ $(R$ 0.942); ( $q$ (released) is a sum of light metal ions released from $1 \mathrm{~g}$ of the biomass to the solution during biosorption process, expressed in the same unit as biosorption capacity, which is synonymous to $q$ (bound) $-q(\mathrm{~b})$ ).

\section{Analysis of the natural and loaded biomass}

Table 1 presents the mineral composition of the natural and loaded biomass. All types of the biomass after biosorption contained in the highest amounts $\mathrm{Ca}$ (II) ions, then $\mathrm{Mg}(\mathrm{II})$ ions, $\mathrm{Na}(\mathrm{I})$ ions and finally $\mathrm{K}(\mathrm{I})$ ions. After the comparison of the composition of loaded and the natural biomass, it can be concluded that the biomass released light metal ions during biosorption process in the following order: $\mathrm{Na}(\mathrm{I})>\mathrm{K}$ (I) $>\mathrm{Mg}$ (II) $>\mathrm{Ca}$ (II) (the average content of $\mathrm{Na}$ (I) in the loaded biomass was 25 times lower than in the natural biomass, the content of K(I) 15 times lower, $\mathrm{Mg}$ (II) 7 times lower and $\mathrm{Ca}(\mathrm{II}) 4$ times). This allows to suppose, that $\mathrm{Na}$ (I) ion was the main alkali metal, which was exchanged during biosorption process with all the examined microelement ions. These data are in accordance with the results obtained in the analysis of the composition of the solution. In Table 2, the balance sheet of microelement ions in the solution and in the biomass is presented. The average recovery for microelement ions was $84 \%$.

\section{Calculation of the biosorption capacity}

On the basis of the composition of the solution, it was possible to evaluate the amount of released metal ions and simultaneously ions bound by the biomass (expressed in molar units (meq $\mathrm{g}^{-1}$ ), which considers the charge of the ion). The multielemental analysis of the solution after the process revealed the presence of cations that were not detected in the solution in high concentrations before the process. It was found that the higher amount of bound microelements $-q(\mathrm{~b})$, the higher amount of released light metals ions- $q(\mathrm{r})$ : $\mathrm{Na}(\mathrm{I}), \mathrm{K}(\mathrm{I}), \mathrm{Mg}(\mathrm{II})$ and $\mathrm{Ca}(\mathrm{II})$. The equation, which shows this relationship is as follows: $q(\mathrm{r})=0.510 \cdot q(\mathrm{~b})+0.980(R 0.918)$.

These data confirmed the hypothesis that ion exchange plays a major role in the binding of metal ions by algal
Table 1 The concentration of light metal ions in the natural and loaded biomass by ICPOES in digested samples of the biomass

\begin{tabular}{|c|c|c|c|c|c|}
\hline \multirow[t]{2}{*}{ Element } & \multicolumn{5}{|c|}{ The composition of the natural and loaded biomass ( $\mathrm{mg} \mathrm{kg}^{-1}$ of dry mass) } \\
\hline & Natural biomass & MA-Mn & MA-Zn & $\mathrm{MA}-\mathrm{Cu}$ & MA-Co \\
\hline K & $3,920 \pm 784$ & $285 \pm 42.7$ & $246 \pm 36.9$ & $213 \pm 31.9$ & $280 \pm 42.0$ \\
\hline $\mathrm{Mg}$ & $8,814 \pm 1763$ & $1,630 \pm 326$ & $1,345 \pm 269$ & $857 \pm 129$ & $1,506 \pm 301$ \\
\hline $\mathrm{Ca}$ & $9,550 \pm 1910$ & $2,789 \pm 558$ & $3,077 \pm 615$ & $1,556 \pm 311$ & $3,077 \pm 615$ \\
\hline $\mathrm{Na}$ & $16,283 \pm 3257$ & $590 \pm 88.5$ & $505 \pm 75.7$ & $417 \pm 62.6$ & $1,107 \pm 221$ \\
\hline
\end{tabular}


Table 2 The balance of microelement ions in $1.0 \mathrm{~L}$ of the solution before and after biosorption process (for biomass concentration $1.0 \mathrm{~g} \mathrm{~L}^{-1}$ )

\begin{tabular}{|c|c|c|c|c|c|c|c|}
\hline \multirow[t]{3}{*}{ Element } & \multicolumn{2}{|c|}{ Before biosorption process } & \multirow[t]{2}{*}{$\sum$} & \multicolumn{2}{|c|}{ After biosorption process } & \multirow[t]{2}{*}{$\Sigma$} & \multirow[t]{2}{*}{ Recovery (\%) } \\
\hline & Solution & Biomass & & Solution & Biomass & & \\
\hline & \multicolumn{7}{|l|}{$\mathrm{mg}$} \\
\hline $\mathrm{Mn}$ & $104 \pm 16$ & $0.0302 \pm 0.0076$ & $104 \pm 16$ & $79.1 \pm 11.9$ & $18.2 \pm 2.7$ & $97.3 \pm 12.2$ & 93.6 \\
\hline $\mathrm{Zn}$ & $163 \pm 25$ & $0.0680 \pm 0.0170$ & $163 \pm 25$ & $94.1 \pm 14.1$ & $31.0 \pm 4.7$ & $125 \pm 15$ & 76.7 \\
\hline $\mathrm{Cu}$ & $215 \pm 32$ & $0.0200 \pm 0.0050$ & $215 \pm 32$ & $132 \pm 20$ & $34.5 \pm 5.2$ & $167 \pm 21$ & 77.4 \\
\hline Co & $118 \pm 18$ & $0.0010 \pm 0.0002$ & $118 \pm 18$ & $76.8 \pm 11.5$ & $27.9 \pm 4.2$ & $105 \pm 12$ & 88.7 \\
\hline
\end{tabular}

Fig. 2 SEM images of: A natural biomass; B MA-Mn; C MA$\mathrm{Zn}$; D MA-Cu; E MA-Co (SEM, Leo Zeiss 435), where: $W D$ working distance, EHT extra high tension, $S E 1$ secondary electrons (Signal A), Mag magnification. $\mathrm{Mag}=1.70 \mathrm{KX}(1700$ magnification)
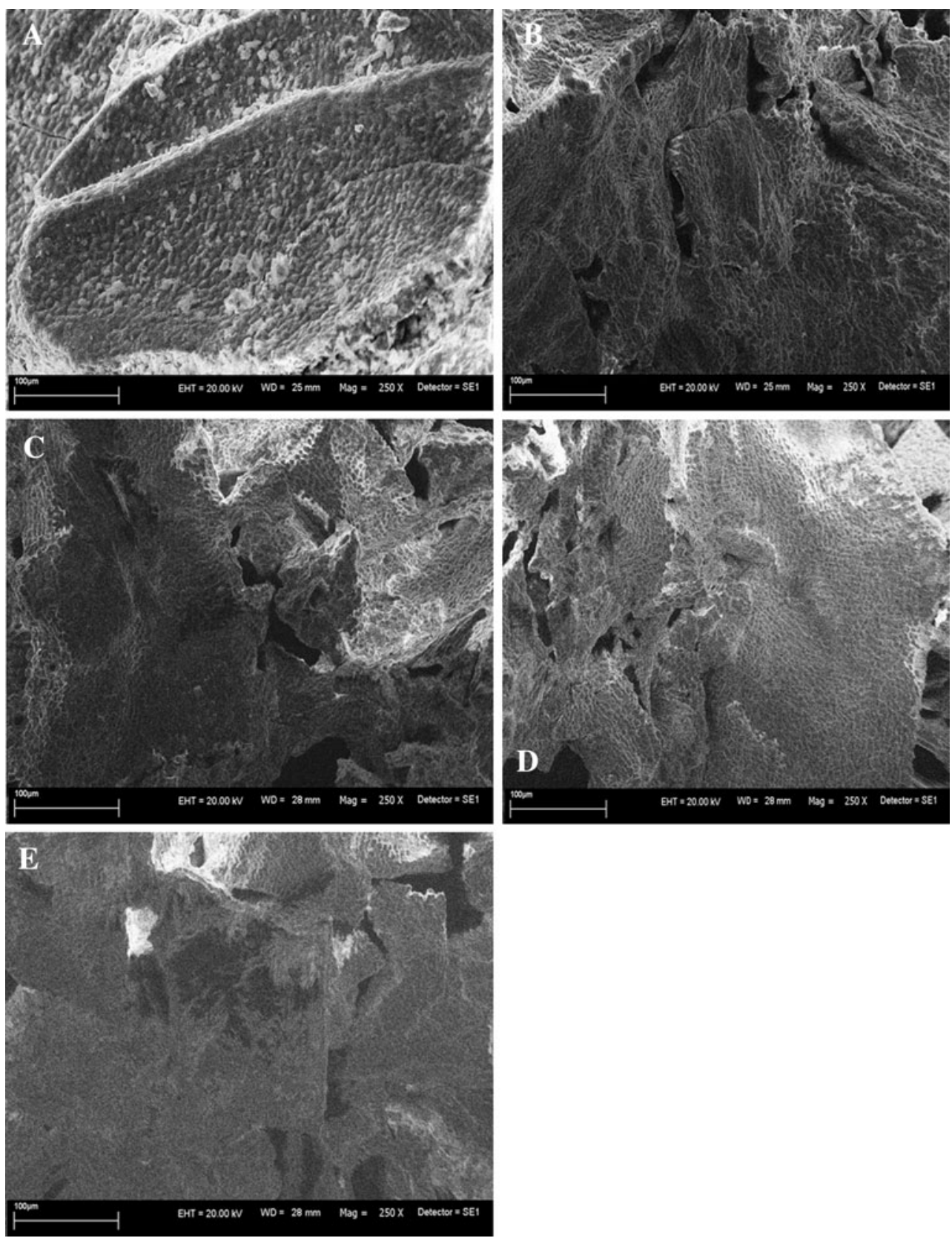
biomass [3]. On the basis of the composition of the solution it can be concluded that $51 \%$ more light metal ions were released than bound microelement ions. This relationship was compared with the data obtained from the analysis of the digested biomass. It was found that Enteromorpha sp. released during biosorption $24 \%$ more light metal ions than bound microelement ions: $q(\mathrm{r})=0.244 \cdot q(\mathrm{~b})+1.51(R 0.608)$. These two values confirmed, that there is a difference in the approach to calculation of biosorption capacity by the two methods. Higher correlation coefficient was obtained in the case of the analysis of the solution composition $(R 0.918)$ than in the case of the biomass composition $(R 0.608)$. In the next step, biosorption capacity determined from the solution $\left(q_{\text {(ICP) }}\right.$; $; \mathrm{mg} \mathrm{g}^{-1}$ or meq $\left.\mathrm{g}^{-1}\right)$ and from the composition of the digested biomass $\left(q_{\text {(ICP) }} \mathrm{X} ; \mathrm{mg} \mathrm{g}^{-1}\right.$ or meq $\left.\mathrm{g}^{-1}\right)$ was compared. The equation, which describes this relationship is as follows: $q^{\mathrm{X}}{ }_{(\mathrm{ICP})}=0.250 \cdot q_{(\mathrm{ICP})}^{\mathrm{S}}+14.2(R 0.940)$. The values of $q_{\text {(ICP) }}^{\mathrm{s}}$ for $\mathrm{Cu}(\mathrm{II}), \mathrm{Mn}$ (II), $\mathrm{Zn}$ (II) and $\mathrm{Co}$ (II) cations were higher (averagely $1.87 \pm 0.52$ ) than the values

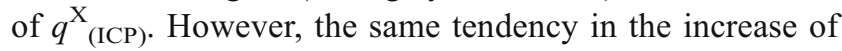
$q$ for microelement cations was obtained $q \mathrm{Cu}(\mathrm{II})>q \mathrm{Zn}$ (II) $>q \mathrm{Co}(\mathrm{II})>q \mathrm{Mn}(\mathrm{II})$.

\section{Scanning electron microscopy}

Scanning Electron Microscopy was used to show macroand ultrastructural changes of the surface of dry biomass of
Fig. 3 X-ray spectrum, mineral trace analysis, RONTEC (SEM, Leo Zeiss 435)-A natural biomass; B MA-Mn; C MA-Zn; D $\mathrm{MA}-\mathrm{Cu} ; \mathbf{E} \mathrm{MA}-\mathrm{Co}$
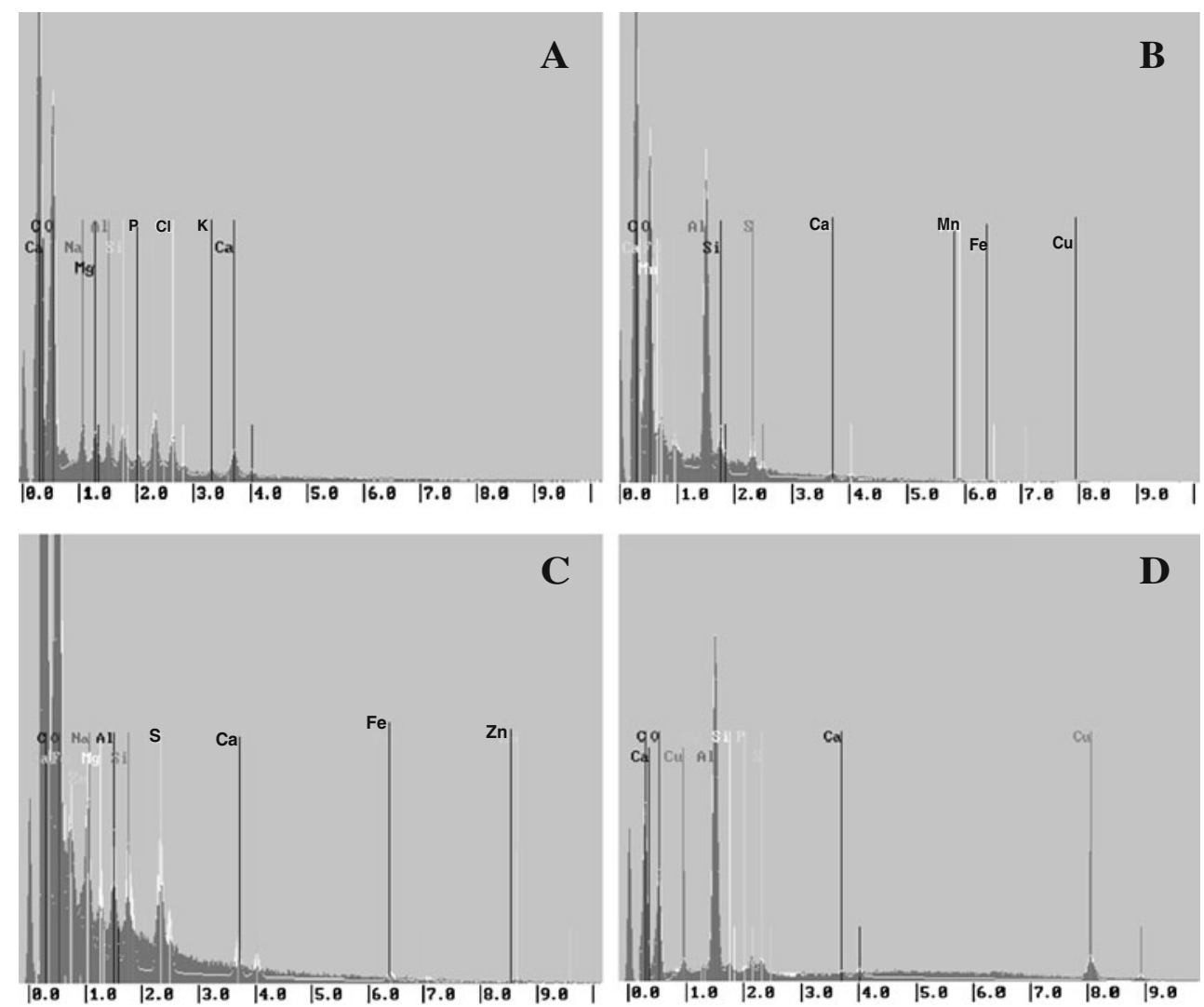

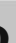

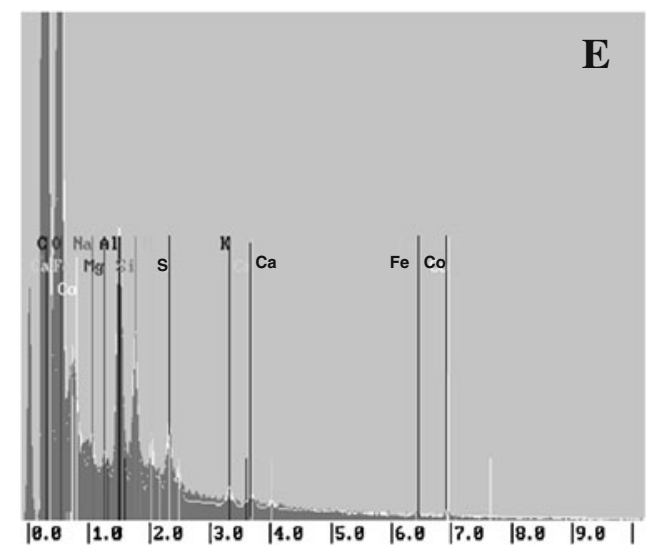


Enteromorpha sp. before and after biosorption process (Fig. 2). General morphological changes of the shape were observed in the case of MA-Mn, MA-Zn, MA-Cu and MA-Co when compared to the natural biomass. SEM electronographs showed detail changes of ultrastructure of macroalgae loaded with microelement ions. All tested macroalgae, except of the natural biomass, were characterized with considerable shrink and possess a tendency to writhe the cell wall. Similar changes were observed by Raize et al. (2004) in the cell wall matrix of Sargassum biomass. Furthermore, breaking of the continuity of the morphological structure and free area between intracellular spaces were observed [17]. It could suggest that different microelement ions were responsible for larger or smaller destruction of the structure by binding ions on the surface.

RONTEC energy dispersive X-ray system (Fig. 3) gave a visible evidence of binding microelement ions on the cell wall of macroalgae. Mapping images clearly showed that $\mathrm{Mn}(\mathrm{II}), \mathrm{Zn}(\mathrm{II}), \mathrm{Cu}(\mathrm{II}), \mathrm{Co}(\mathrm{II})$ ions were sorbed on the surface of Enteromorpha sp. after biosorption (Fig. 4). Specific localization of microelement ions on the surface of macrolagae was observed. All the tested macroalgae showed qualitative and quantitative changes in ions binding to the surface. Different concentration and localization of ions were indicated by appropriate colors. In the case of the natural biomass, the distribution of ions on the surface was uniform (Fig. 4A). On the surface of macroalga loaded with
Fig. 4 X-ray mapping of SEM images, mineral trace analysis, RONTEC (SEM, Leo Zeiss 435) - A natural biomass; B MA-Mn; C MA-Zn; D MA-Cu; E MA-Co. Where: Cblue, S-orange, Ca-green, Al-yellow, Si-brown, A natural biomass - Mg-purple, Cl-red; B MA-Mn - Mn- violet; C MA-Zn - Zn-green, Mg-bright green; D $\mathrm{MA}-\mathrm{Cu}$ - Cu-red, P-bright green; E MA-Co Co-red
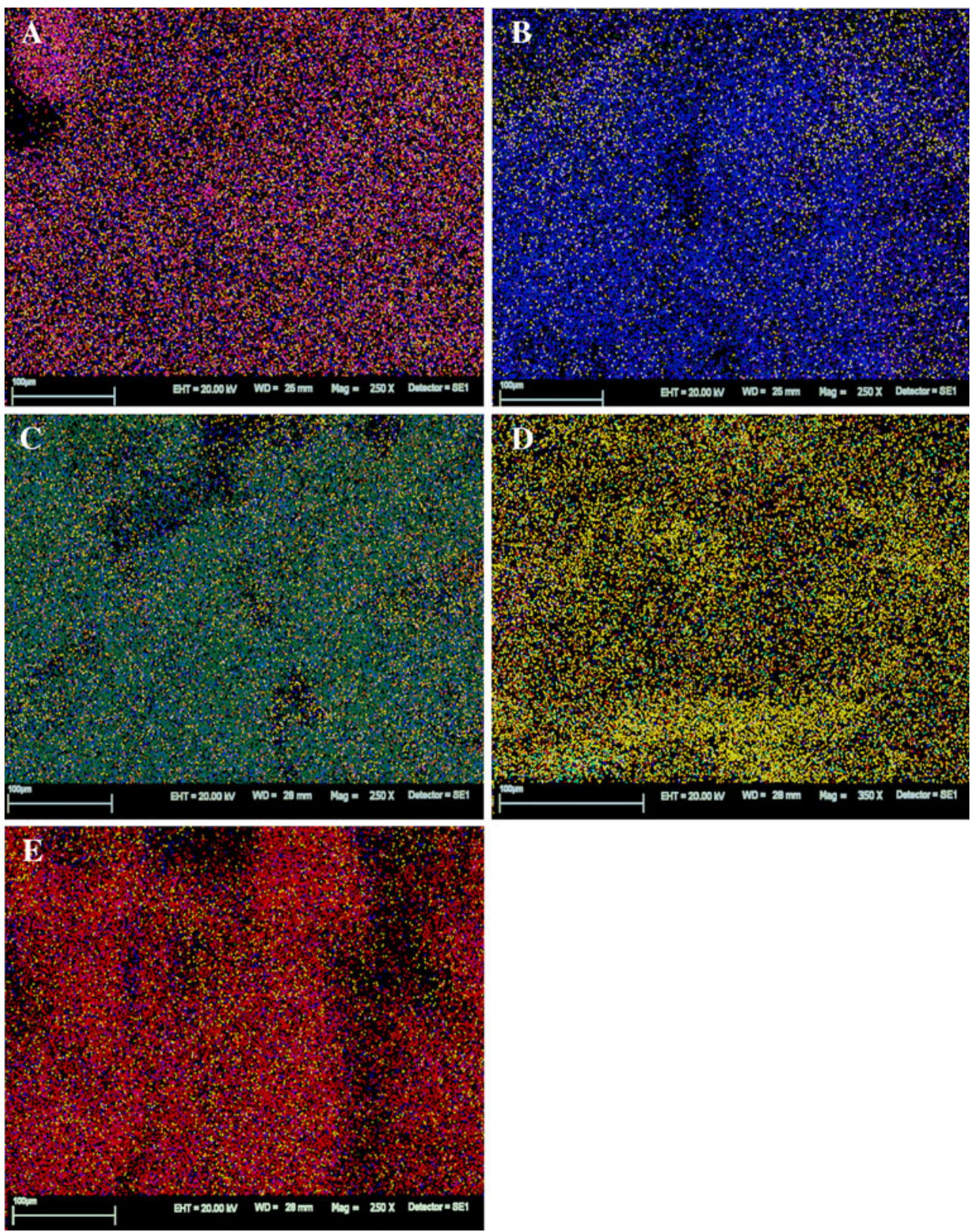
$\mathrm{Mn}(\mathrm{II}), \mathrm{Zn}(\mathrm{II}), \mathrm{Cu}(\mathrm{II})$ and $\mathrm{Co}(\mathrm{II})$ cations (Fig. 4B-E, respectively), overbalance of these ions was found. It is visible as dense clusters giving glaring and intensive color.

Table 3 shows the atomic concentrations of $\mathrm{Mn}(\mathrm{II}), \mathrm{Zn}$ (II), $\mathrm{Cu}(\mathrm{II}), \mathrm{Co}(\mathrm{II})$ in the different metal-laden Enteromorpha sp. samples, according to the analysis of X-ray spectrum. The changes in algal biomass observed after metal uptake included generally increases in carbon concentrations (with exception of MA-Cu) and decreases in sulfur (with exception of MA-Zn), oxygen (with exception of MA-Cu), calcium and magnesium (with exception of MA-Zn). These data are in accordance with the results obtained by Raize et al. 2004, who observed similar changes in $\mathrm{C}, \mathrm{S}, \mathrm{O}, \mathrm{Ca}$ and $\mathrm{Mg}$ concentration after biosorption of heavy metals $(\mathrm{Cd}, \mathrm{Ni}, \mathrm{Pb})$ by Sargassum [17]. In the case of Enteromorpha sp. the biggest changes concerned the concentration of oxygen, since, as it was previously shown [21], carboxyl groups play the dominant role in biosorption process (oxygen was probably covered by microelement ions).

For the natural biomass of Enteromorpha sp.-Fig. 3A showed that $\mathrm{C}, \mathrm{O}, \mathrm{S}, \mathrm{Cl}$ and $\mathrm{Ca}$ constituted the major elements of the surface of macroalgal cell, and $\mathrm{Mn}, \mathrm{Zn}, \mathrm{Cu}$ and Co signals were not detected in the X-ray spectrum. After biosorption of $\mathrm{Mn}(\mathrm{II}), \mathrm{Zn}(\mathrm{II}), \mathrm{Cu}(\mathrm{II}), \mathrm{Co}(\mathrm{II})$ ions signals were clearly observed in Fig. 3B-E, respectively. This means that a remarkable amount of microelements was adsorbed by the cell surface of Enteromorpha sp.
Table 4 Correlation matrix between the results obtained by ICP-OES and SEM-EDX from the biosorption of $\mathrm{Mn}(\mathrm{II}), \mathrm{Co}(\mathrm{II}), \mathrm{Zn}(\mathrm{II})$ and $\mathrm{Cu}$ (II) ions, $(N=4)$

\begin{tabular}{lllll}
\hline & $C_{\text {LAD.(ICP) }}^{\mathrm{X}}$ & $C_{\text {LAD.(SEM) }}^{\mathrm{X}}$ & $q_{\text {(ICP) }}^{\mathrm{S}}$ & $q_{\text {(ICP) }}^{\mathrm{X}}$ \\
\hline$C^{\mathrm{X}}{ }_{\text {LAD.(ICP) }}$ & 1.00 & & & \\
$C_{\text {LAD.(SEM) }}^{\mathrm{X}}$ & 0.681 & 1.00 & & \\
$q_{\text {(ICP) }}^{\mathrm{S}_{\text {(ICP) }}}$ & $0.941^{* *}$ & 0.784 & 1.00 & \\
$q_{\text {(ICP) }}^{\mathrm{X}}$ & $1.00^{*}$ & 0.681 & $0.940^{* *}$ & 1.00 \\
\hline
\end{tabular}

Correlation coefficient is significant: *at $p<0.05$; ** at $p<0.1$

Where:

$C_{\text {LAD.(ICP) }}^{\mathrm{X}}$ the concentration of elements in the metal-laden biomass, $\mathrm{mg} \mathrm{kg}^{-1}$

$C_{\text {LAD.(SEM) }}^{\mathrm{X}}$ the atomic concentration of elements on the surface of the metal-laden biomass, \%

The comparison of biosorption performance by ICP-OES and SEM

The aim of this section was to compare data obtained by ICP-OES and SEM-EDX, in order to point out the best method of evaluation of biosorption performance. In order to find the correlations between the results obtained by both methods, a correlation matrix was prepared (Table 4) with the STATISTICA (v.8) software. The application of the statistical analysis revealed statistically significant correlation:

Table 3 Atomic concentration of elements (\%) on the surface of natural and metal-laden biomass of Enteromorpha sp. (according to the analysis of X-ray spectrum)

\begin{tabular}{|c|c|c|c|c|c|c|}
\hline \multirow[t]{2}{*}{ Element } & & \multicolumn{5}{|c|}{ Atomic concentration of elements ( $\%$ of all detected ions) } \\
\hline & & MA-natural & MA-Mn & MA-Zn & $\mathrm{MA}-\mathrm{Cu}$ & MA-Co \\
\hline \multirow[t]{5}{*}{ Macroelements } & $\mathrm{C}$ & $50.4 \pm 8.27$ & $53.7 \pm 9.02$ & $54.3 \pm 9.64$ & $35.4 \pm 6.71$ & $61.0 \pm 9.97$ \\
\hline & $\mathrm{O}$ & $40.9 \pm 6.82$ & $33.5 \pm 5.95$ & $30.1 \pm 6.00$ & $47.6 \pm 8.61$ & $31.7 \pm 5.53$ \\
\hline & $\mathrm{P}$ & $0.63 \pm 0.06$ & $<$ LLD & $<$ LLD & $0.46 \pm 0.08$ & $0.87 \pm 0.08$ \\
\hline & $\mathrm{S}$ & $2.12 \pm 0.10$ & $1.98 \pm 0.12$ & $5.31 \pm 0.30$ & $0.50 \pm 0.08$ & $1.44 \pm 0.10$ \\
\hline & $\mathrm{Cl}$ & $1.58 \pm 0.10$ & $<\mathrm{LLD}$ & $<$ LLD & $<\mathrm{LLD}$ & $<\mathrm{LLD}$ \\
\hline \multirow[t]{5}{*}{ Microelements } & $\mathrm{Fe}$ & $<$ LLD & $0.07 \pm 0.08$ & $0.80 \pm 0.21$ & $<\mathrm{LLD}$ & $0.04 \pm 0.06$ \\
\hline & $\mathrm{Cu}$ & $<$ LLD & $0.05 \pm 0.08$ & $<\mathrm{LLD}$ & $5.27 \pm 0.51$ & $<\mathrm{LLD}$ \\
\hline & $\mathrm{Mn}$ & $<$ LLD & $0.11 \pm 0.10$ & $<$ LLD & $<\mathrm{LLD}$ & $<\mathrm{LLD}$ \\
\hline & $\mathrm{Zn}$ & $<$ LLD & $<\mathrm{LLD}$ & $0.64 \pm 0.27$ & $<\mathrm{LLD}$ & $<$ LLD \\
\hline & $\mathrm{Co}$ & $<\mathrm{LLD}$ & $<\mathrm{LLD}$ & $<$ LLD & $<\mathrm{LLD}$ & $0.09 \pm 0.08$ \\
\hline \multirow[t]{4}{*}{ Alkali and alkaline earth metals } & $\mathrm{K}$ & $0.30 \pm 0.07$ & $<$ LLD & $<$ LLD & $<$ LLD & $0.31 \pm 0.08$ \\
\hline & $\mathrm{Ca}$ & $1.16 \pm 0.10$ & $0.48 \pm 0.08$ & $1.54 \pm 0.16$ & $0.23 \pm 0.06$ & $0.25 \pm 0.06$ \\
\hline & $\mathrm{Mg}$ & $0.62 \pm 0.05$ & $<$ LLD & $1.56 \pm 0.12$ & $0.11 \pm 0.07$ & $0.19 \pm 0.05$ \\
\hline & $\mathrm{Na}$ & $0.746 \pm 0.06$ & $<\mathrm{LLD}$ & $<$ LLD & $<\mathrm{LLD}$ & $0.29 \pm 0.05$ \\
\hline
\end{tabular}

$<L L D$ below low limit of detection

Italics below/or above limit of detection (\%): C (0.277-100); O (0.525-100); P (0.001-2.013); S (0.001-2.307); $\mathrm{Cl}$ (10.001-2.621); Fe (0.0606.398); $\mathrm{Cu}$ (0.083-8.040); Mn (0.063-5.894); Zn (0.001-8.630); Co (0.076-6.924); K (0.001-3.312); Ca (0.341-3.690); Mg (0.001-1.553); Na $(0.001-1.041)$ 
at $p<0.1 q_{(\mathrm{ICP})}^{\mathrm{S}} C_{\text {LAD.(ICP) }}^{\mathrm{X}}(R \quad 0.941), q_{(\mathrm{ICP})^{-}}^{\mathrm{X}} q_{(\mathrm{ICP})}^{\mathrm{S}}$ $(R 0.940)$ and at $p<0.05 q^{\mathrm{X}}{ }_{(\mathrm{ICP})}{ }^{-} C^{\mathrm{X}}{ }_{\text {LAD.(ICP) }}(R \quad 1.00)$.

On the basis of the conducted experiments, it can be concluded that traditionally used method of evaluation of biosorption capacity (from mass balance) is more appropriate than from the composition of the natural and loaded biomass. Relatively low value of correlation coefficient for the pair: $C_{\text {LAD.(SEM) }}^{\mathrm{X}}-C_{\text {LAD.(ICP) }}^{\mathrm{X}}\left(\begin{array}{ll}R & 0.681\end{array}\right)$ can be explained by the fact, that $C_{\text {LAD.(ICP) }}^{\mathrm{X}}$ concerned the content of the microelements both - inside and outside the biomass, whereas $C_{\text {LAD.(SEM) }}^{\mathrm{X}}$ only content of the elements on the cell surface after biosorption process. Moreover, EDX in conjunction with SEM is a surface analysis method and furthermore, for small concentrations this system is not very precise and the detection limit is dependent on the matrix and its surface [24]. The strong variation of the EDX results in different sample areas is the consequence of a typical behaviour of the SEM-EDX, it is surface analysis, and shows therefore only a part of the whole analytical information, this is in total contrast to conventional ICPOES, which shows average results for every sample [19].

\section{Conclusion}

It is necessary to combine different methods to explore the mechanisms of metal biosorption. ICP method is especially valuable in determination of the mineral content of the whole (outside and inside) biological samples, whereas SEM technique is useful in detection of elements on the surface of samples. Moreover, it is possible to map the elements on the cell wall of the biomass and to observe morphological changes in the cell wall matrix.

Both techniques confirmed that biosorption is a surface phenomenon, in which alkali and alkaline earth metals were exchanged with microelement ions from the aqueous solution. ICP method revealed that $\mathrm{Na}(\mathrm{I})$ was the main alkali metal, which was exchanged during the biosorption process. It was released in the highest quantities from the biomass to the solution, which can be connected with the highest concentration of this element in the natural biomass from among other examined elements (Ca(II), $\mathrm{Mg}(\mathrm{II}), \mathrm{K}$ (I)). It was also found that the higher quantity of released light metals ions $-q(\mathrm{r}): \mathrm{Na}(\mathrm{I}), \mathrm{K}(\mathrm{I}), \mathrm{Mg}(\mathrm{II})$ and $\mathrm{Ca}(\mathrm{II})$, the higher quantity of bound microelement ion $-q(\mathrm{~b})$.

The experiments showed that there is a difference in the value of biosorption capacity calculated from the mass balance and from the biomass composition. The $q$ values determined from the first method were higher than from the second-averagely $1.87 \pm 0.52$. However, the same tendency in the increase of $q$ for microelement ions was obtained $q \mathrm{Cu}(\mathrm{II})>q \mathrm{Zn}(\mathrm{II})>q \mathrm{Co}(\mathrm{II})>q \mathrm{Mn}$ (II). The correlation coefficient was 0.940 .
The analysis of the biomass by SEM technique showed that all the tested macroalgae, except of the natural biomass, were characterized by considerable shrink and writhe of the cell wall. It could suggest that different microelement ions were responsible for larger or smaller destruction of the structure by binding them on the surface. RONTEC energy dispersive X-ray system gave a visible evidence of binding microelement ions on the cell wall of macroalgae. Mapping images clearly showed that $\mathrm{Mn}(\mathrm{II})$, $\mathrm{Zn}(\mathrm{II}), \mathrm{Cu}(\mathrm{II}), \mathrm{Co}$ (II) ions were sorbed on the surface of Enteromorpha sp. after the process of enrichment.

The final conclusion of our work is that the most appropriate way is to analyze the samples with both systems: first qualitative and quantitative overview by SEM-EDX and then a precise quantification of the results by ICP-OES.

Acknowledgments This research was financially supported by Polish Ministry of Science and Higher Education (grant No. R05 $01401)$.

Open Access This article is distributed under the terms of the Creative Commons Attribution Noncommercial License which permits any noncommercial use, distribution, and reproduction in any medium, provided the original author(s) and source are credited.

\section{References}

1. Davis TA, Volesky B, Mucci A (2003) A review of the biochemistry of heavy metal biosorption by brown alga. Water Res 37:4311-4330

2. Yun Y-S, Park D, Park JM, Volesky B (2001) Biosorption of trivalent chromium on the brown seaweed biomass. Environ Sci Technol 35:4353-4358

3. Schiewer S, Volesky B (1996) Modeling multi-metal ion exchange in biosorption. Environ Sci Technol 30:2921-2927

4. Kumar Prasanna Y, King P, Prasad VSRK (2006) Removal of copper from aqueous solution using Ulva fasciata sp.-a marine green alga. J Hazard Mater B137:367-373

5. Sheng PX, Ting YP, Chen JP, Hong L (2004) Sorption of lead, copper, cadmium, zinc, and nickel by marine algal biomass: characterization of biosorptive capacity and investigation of mechanisms. J Colloid Interface Sci 275:131-141

6. Denkhaus E, Meisen S, Telgheder U, Wingender J (2007) Chemical and physical methods for characterisation of biofilms. Microchim Acta 158:1-27

7. Rupérez P (2002) Mineral content of edible marine seaweeds. Food Chem 79:23-26

8. Żbikowski R, Szefer P, Latała A (2006) Distribution and relationships between selected chemical elements in green alga Enteromorpha sp. from the southern Baltic. Environ Pollut 143:435-448

9. Murphy V, Hughes H, McLoughlin P (2008) Comparative study of chromium biosorption by red, green and brown seaweed biomass. Chemosphere 70:1128-1134

10. Csikkel-Szolnoki A, Báthori M, Blunden G (2000) Determination of elements in algae by different atomic spectroscopic methods. Microchem J 67:39-42

11. Michalak I, Chojnacka K (2008) The application of macroalga Pithophora varia Wille enriched with microelements by biosorption 
as biological feed supplement for livestock. J Sci Food Agric 88: $1178-1186$

12. Tsezos M, Remoudaki E, Angelatou V (1997) Biosorption sites of selected metals using electron microscopy. Comp Biochem Physiol A Physiol 118:481-487

13. Herrero R, Lodeiro P, Rey-Castro C, Vilarino T, Sastre de Vicente ME (2005) Removal of inorganic mercury from aqueous solutions by biomass of the marine macroalga Cystoseira baccata. Water Res 39:3199-3210

14. Han X, Wong YS, Tam NFY (2006) Surface complexation mechanism and modeling in $\mathrm{Cr}$ (III) biosorption by a microalgal isolate Chlorella miniata. J Colloid Interface Sci 303:365-371

15. Akar T, Tunali S (2005) Biosorption performance of Botrytis cinerea fungal by-products for removal of $\mathrm{Cd}(\mathrm{II})$ and $\mathrm{Cu}(\mathrm{II})$ ions from aqueous solutions. Min Eng 18:1099-1109

16. Sheng PX, Wee KH, Ting YP, Chen JP (2008) Biosorption of copper by immobilized marine algal biomass. Chem Eng J 136: $156-163$

17. Raize O, Argaman Y, Yannai S (2004) Mechanisms of biosorption of different heavy metals by brown marine macroalgae. Biotechnol Bioeng 87:451-458
18. Yu Q, Kaewsarn P, Van Duong L (2000) Electron microscopy study of biosorbents from marine macroalga Durvillaea potatorum. Chemosphere 41:589-594

19. Einhäuser TJ (1997) ICP-OES and SEM-EDX analysis of dust and powder produced by the laser-processing of a Cr-Ni-steel alloy. Mikrochim Acta 127:265-268

20. Dodson JR, Aronson JM (1978) Cell wall composition of Enteromorpha intestinalis. Bot Mar 21:241-246

21. Michalak I, Chojnacka K (2009) Edible macroalga Ulva prolifera as microelemental feed supplement for livestock: the fundamental assumptions of the production method. World J Microbiol Biotechnol 25:997-1005

22. Michalak I, Chojnacka K (2010) The new application of biosorption properties of Enteromorpha prolifera. Appl Biochem Biotechnol 160:1540-1556

23. Chojnacka K (2006) The application of multielemental analysis in the elaboration of technology of mineral feed additives based on Lemna minor biomass. Talanta 70:966-972

24. Quevauviller P, Imbert JL, Olle M (1993) Evaluation of the use of microwave-oven systems for the digestion of environmental samples. Mikrochim Acta 112:147-154 